\title{
INDIRECT EFFECTS OF CLIMATE CHANGE ON ZINC CYCLING IN SEDIMENTS: THE ROLE OF CHANGING WATER LEVELS
}

\author{
SARa M. Nedrich ${ }^{\mathrm{a}, *}$ and G. Allen Burton ${ }^{\mathrm{b}}$ \\ ${ }^{a}$ Department of Earth and Environmental Sciences, University of Michigan, Ann Arbor, Michigan, USA \\ ${ }^{\mathrm{b}}$ School of Natural Resources and Environment, University of Michigan, Ann Arbor, Michigan, USA
}

(Submitted 17 November 2016; Returned for Revision 31 January 2017; Accepted 1 March 2017)

\begin{abstract}
Increased variability in lake and river water levels associated with changing climate could impact the fate and effects of metals in redox-sensitive sediments through the alteration of microbial communities and of acid-base and redox chemistry. The objective of the present study was to determine the influence of water level fluctuation on metal speciation in porewater and predict environmental risk to high-carbonate systems. Using experimental microcosms with sediments collected from 4 metal-contaminated coastal freshwater wetlands in Michigan, USA, we conducted water level fluctuation experiments. Porewater and sediment metals $(\mathrm{Ca}, \mathrm{Cu}, \mathrm{Fe}, \mathrm{Mg}, \mathrm{Mn}, \mathrm{Ni}$, $\mathrm{Zn}$ ) and important metal binding phases (iron-oxide speciation, acid-volatile sulfide) were quantified. In a short-term drying (seiche) experiment, there were decreases in all porewater metals after inundation of saturated sediments. During a drought experiment, reinundation of oxidized sediments increased porewater $\mathrm{Cu}, \mathrm{Zn}, \mathrm{Mg}, \mathrm{Ca}$ for most sites. Porewater $\mathrm{Zn}$ increased after inundation to levels exceeding the US Environmental Protection Agency threshold for chronic toxicity. These data show that the dissolution of metal carbonates and metal sulfates contributes to metal release after re-flooding and indicate that we might expect increased ecological risk to organisms present in drought-sensitive regions where altered hydroperiods are likely to increase metal bioavailability. Environ Toxicol Chem 2017;36:2456-2464. (C) 2017 SETAC
\end{abstract} $\begin{array}{lllllll}\begin{array}{l}\text { Keywords: } \\ \text { cycling }\end{array} & \text { Metals } \quad \text { Ecotoxicology } & \text { Sediments level fluctuation } & \text { Wetlands } & \text { Climate change } & \text { Redox } & \text { Biogeochemistry }\end{array}$

\section{INTRODUCTION}

Climate change is affecting regional hydrology, with collateral effects on the biogeochemistry of aquatic systems [1]. Although climate is variable in nature, the magnitude, frequency, timing, and duration of precipitation or flooding events (hydroperiod) are expected to be altered significantly on a regional basis by warming global temperatures [2]. Increased water level fluctuation affects coastal ecosystem biogeochemistry by altering sediment acid-base chemistry, redox potential, and microbial community response, which can facilitate release or sorption of metal contaminants [3]. These processes are relevant to several hydrologic types, such as streams and wetlands.

The fate and release of metal contaminants are controlled primarily by the abundance and reactivity of ligands that bind metals, thereby reducing their ecotoxicity. Many metals of concern $(\mathrm{Zn}, \mathrm{Cu}$, and $\mathrm{Ni})$ are primarily toxic to organisms in their +2-oxidation state, when dissolved. The primary objectives of the present study were to determine the influence of water level fluctuation on metal speciation in porewater and sediments, to identify the key binding ligands associated with metal flux, and to discuss potential effects to benthic macroinvertebrate populations.

Many ligands are sensitive to redox, $\mathrm{pH}$, or microbial changes associated with water level fluctuations, including Fe/Mn-oxyhydroxides, metal sulfides, and metal carbonates. Oxygen fluxes affect the formation and dissolution of Fe/Mnoxyhydroxides, which can release or bind metals [4]. Another

This article includes online-only Supplemental Data

* Address correspondence to snedrich@umich.edu

Published online 6 March 2017 in Wiley Online Library

(wileyonlinelibrary.com).

DOI: $10.1002 /$ etc. 3783 primary fate process of these metals is binding to sulfide complexes under reduction and release after oxidation of sediments [5]. In this reaction, sediment microbes kinetically mediate the production and oxidation of sulfide. Although the formation of metal carbonates is less influenced by redox or microbial activity, it is highly a function of $\mathrm{pH}$, which has been shown to increase after reduction of oxidized sediments [6]. Yet another primary binding phase is organic carbon, which is thought to be less affected by redox state and varies in importance, depending on the metal of interest [7]. Predicting sediment toxicity in hydrologically dynamic watersheds is nuanced because of the complexity of formation of these compounds.

Sediments with low acid neutralizing capacity (such as acidsulfate or low-carbonate systems) are very sensitive to hydrologic pulses. In one study in Hamburg Harbor, Germany, oxidation of reduced sediments led to a decrease in $\mathrm{pH}$ from 8 to 4 , leading to release of metals into the water column [8]. Recent work investigating effects of flooding on the drought-induced floodplain of Australia's Lower Murray River similarly showed a sudden decrease in $\mathrm{pH}$ after inundation, attributable to release of iron sulfate, with acidity persisting in sediments for more than $3 \mathrm{yr}$ after the initial inundation $[9,10]$. Further studies of sulfide oxidation focus on treatment of acid mine drainage, more specifically using the Global Acid Rock Drainage guide to predict geochemical behavior of waste rock [11].

Work investigating the role of hydroperiod on metal dynamics in medium-high-acid neutralizing capacity freshwater systems has focused primarily on nutrient availability and has not been linked to metal toxicity. Reflooding of oxidized sediment as a part of a wetland restoration led to eventual reduction of Fe and release of phosphate into surface water [12]. Steinman et al. [13] showed similar results in a controlled laboratory testing of coastal Great Lakes wetland sediments 
after 8 wk of soil desiccation. These studies suggest $\mathrm{Fe}$ oxidation plays an important role in hydrologically dynamic sediments, which may influence the fate of other metals.

One metal-centric study of a high-acid neutralizing capacity floodplain forest along the upper Mississippi River (La Crosse, WI, USA) found an increase in porewater $\mathrm{Zn}$ and other metals during a 4-mo oxidation period [14]. In a freshwater tidal wetland in Virginia, USA, Seybold et al. [15] showed a direct correlation of oxidation and acidification, which helps explain why metal flux is being observed in low-acid systems. Further evidence is needed to show whether metal flux associated with water level fluctuation in high-carbonate sediments are likely to induce effects to macroinvertebrate populations.

We predict that inundation of oxidized sediments will lead to a release of previously sediment-bound metals; that long-term drought events will produce higher porewater metal bioavailability and theoretical toxicity than short-term, seiche events, as a result of an increase in oxidized sediment fraction; and that sulfide, iron/manganese oxides, and carbonate-binding ligands will be the primary controls on metal flux. These data will help predict the effect of climate-induced water level fluctuation on metal cycling and toxicity in the freshwater systems, such as the Great Lakes, and inform continued management and protection of wetland and shallow-water ecosystems.

\section{METHODS}

\section{Site/sediment selection}

We selected 4 coastal lacustrine wetlands of high sediment metal content, variable hydrology, and diverse sediment chemical composition and grain size (all minerotrophic). By selecting several sites, we can compare effects of sediment type and improve relatability to multiple field conditions. The sites selected were Quanicassee Wildlife Refuge (QC), East Bay Park (EB), Little Black Creek (LBC), and Lake Erie Metropark Wetlands (DRW). A map of sediment collection sites is provided in Figure 1, with additional site description in the Supplemental Data. We also collected nonpolluted sediments as a control from the River Raisin (RAIS) in Manchester, Michigan. A detailed comparison of site characteristics is provided in Table 1.

\section{Experimental design}

Sediment columns were extracted intact with a trenching shovel from each site and placed in 3 replicate microcosm chambers per site (November 2014). Sediments were irrigated and remained saturated at room temperature to support microbial life until experiments began in January 2015. Microcosm design is depicted in Figure 2. Input water chemical composition is similar to Great Lakes surface water, with an average of $152.9 \pm 1.4 \mathrm{mg} \mathrm{L}^{-1} \mathrm{CaCO}_{3}, 6.2 \pm 0.02 \mathrm{mg} \mathrm{L}^{-1} \mathrm{O}_{2}$, $7.6 \pm 0.1 \mathrm{pH}, 40.7 \pm 0.4 \mathrm{mg} \mathrm{L}^{-1} \mathrm{Na}, 3.4 \pm 0.3 \mathrm{mg} \mathrm{L}^{-1} \mathrm{~K}$, and approximately $0.15 \mathrm{mg} \mathrm{L}^{-1} \mathrm{Cl}$. Concentrations of other metals in input water were below detection $\left(\sim 5 \mu \mathrm{g} \mathrm{L}^{-1}\right)$. The flow rate was constant at $1.55 \pm 0.5 \mathrm{~cm}^{3} \mathrm{~s}^{-1}$ during water additions.

Two experiments mimicking a seiche (short-term drying) and a month-long drought were conducted, both with sediment drying followed by sediment rewetting ( $15 \mathrm{~h}$ and $32 \mathrm{~d}$ for seiche and drought, respectively). The seiche and drought hydroperiod were chosen due to their frequency of occurrence in Great Lakes systems. Seiches occur during storm events, when wind pushes water to one side of a lake, causing a basin-wide standing wave. The month-long drought was designed to mimic seasonal low water (dry season) and high water (wet season).

Surface water was drained from microcosms with a $250-\mu \mathrm{m}$ mesh syringe during drying, with additional drainage from a small $1-\mathrm{cm}$ hole in the bottom of each chamber. An over-head drip system was used to re-inundate sediments, and the drainage hole in the bottom of each chamber was left open (seiche) or closed (drought). This irrigation system emulated precipitation and may have slightly different results than a groundwater-fed system because of the potential for trapped air in microcosm sediments. Excess water overflowed into a drainage basin and was discarded. During the seiche and drought experiments, water was refreshed for 10 min every $6 \mathrm{~h}$ or for 4 min every $24 \mathrm{~h}$, respectively.

\section{Sampling and lab analysis}

Porewater metals were sampled at all depths before and after $15 \mathrm{~h}$ of reflooding (for seiche) or after 1, 11, 16, 32 d of reflooding (for drought). Additional sampling for redox parameters (dissolved oxygen and reduced $\mathrm{Fe}$ ) occurred on

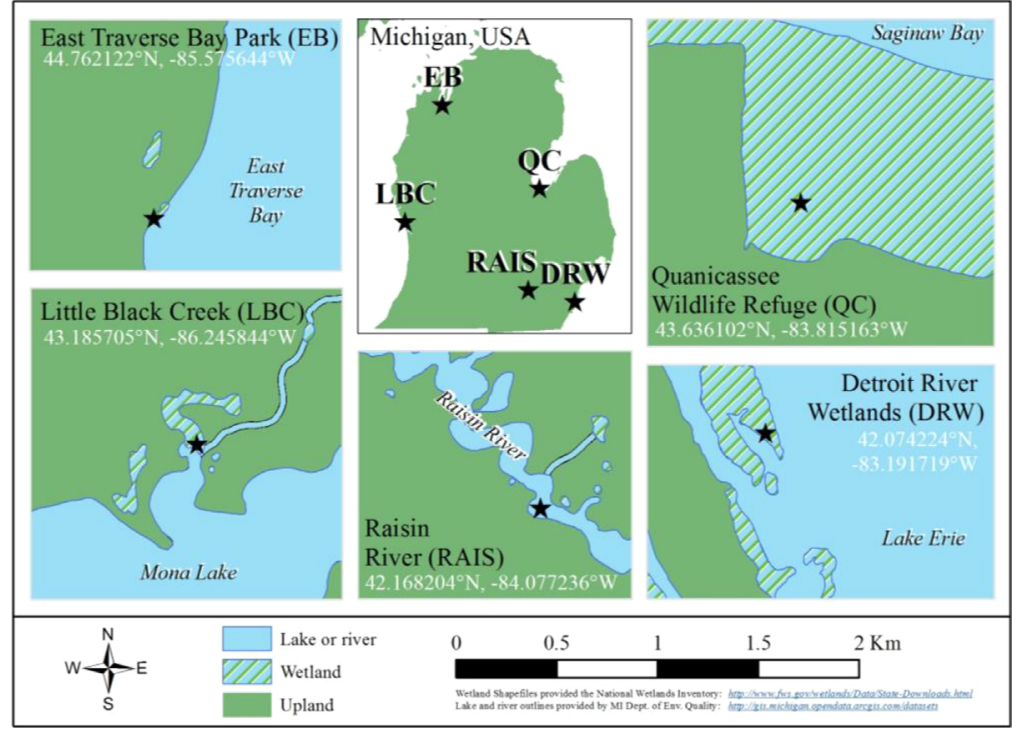

Figure 1. Location of wetland sites along the coast of Michigan, USA. 


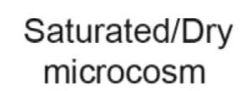

Inundated microcosm
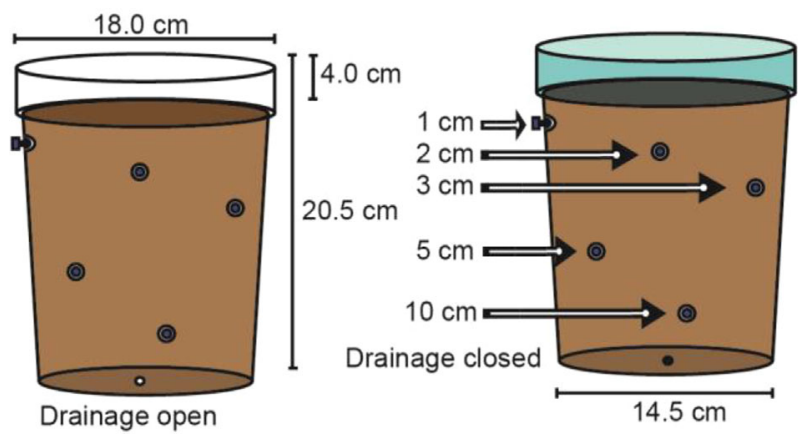

Figure 2. Experimental microcosm design during dry and inundated sediment phases. Rhizon porewater samplers were inserted at depths of 1,2, 3,5 , and $10 \mathrm{~cm}$.

days 3, 9, and 24 (for drought). Water was extracted with a nitrogen-purged syringe. A maximum volume of $15 \mathrm{~mL}$ porewater was filtered through Rhizon samplers to $0.19 \mu \mathrm{m}$, and surface waters were filtered with a $0.45-\mu \mathrm{m}$ Millipore syringe-attachable filter. Dissolved oxygen in porewater was immediately measured using a $100-\mu \mathrm{m}$-diameter oxygen microelectrode. Filtered samples were then acidified with trace metal grade nitric acid to $2 \%$, stored in the dark at $4{ }^{\circ} \mathrm{C}$, and analyzed within $1 \mathrm{mo}$ on an inductively coupled plasmaoptical emission spectrometer (ICP-OES) for metals $\mathrm{Cu}, \mathrm{Ni}$, $\mathrm{Zn}$, and other important metals associated with binding $(\mathrm{Ca}$, $\mathrm{Fe}, \mathrm{Mg}$, and $\mathrm{Mn})$. Metal detection limits were $\sim 5$ to $10 \mu \mathrm{gL}^{-1}(\mathrm{Cu}, \mathrm{Ni}, \mathrm{Zn})$ or $50 \mu \mathrm{g} \mathrm{L}^{-1}(\mathrm{Ca}, \mathrm{Fe}, \mathrm{Mg}, \mathrm{Mn})$. Concentrations were corrected using a procedural blank (run for every 30 samples). Additional porewater was sampled and quickly analyzed for reduced iron $\left(\mathrm{Fe}^{2+}\right)$ concentration using a colorimetric (ferrozine) method [16]. Porewater dissolved organic carbon (DOC) was analyzed after acidification (with $6 \mathrm{M} \mathrm{HCl}$ to a $\mathrm{pH}$ of 2) on an Aurora 1030 TOC Analyzer (OI Analytical).

Dry and wet phase sediment cores were extracted from each microcosm on the day prior to re-inundation, 15 or $24 \mathrm{~h}$ after inundation, and (for drought experiment) 1 and $32 \mathrm{~d}$ after inundation. Sediment cores were sectioned with an acidcleaned plastic spatula into $1.5-\mathrm{cm}$ increments in a $\mathrm{N}_{2}$ filled, continuous-flow purging bag. Sediment was processed for acid volatile sulfide (AVS) content and simultaneously extracted metals (SEM) [17], iron oxide crystalline and amorphous content [18], dry weights, and loss on ignition (6$\mathrm{h}$ combustion at $450^{\circ} \mathrm{C}$ ) for organic carbon content. Replicate procedural blanks and reference sediments were run with digestions to verify $>80 \%$ recovery between iron oxide extractions and to correct for reagent-associated metals. Extracted metal solutions were analyzed on an ICP-OES. Sediment $\mathrm{pH}$ was measured using a sediment probe.

\section{Statistical analysis}

Significance testing was conducted on 2 levels: a multisite level, including all microcosms as one sample, and a single-site level, looking at individual sites (QC, EB, DRW, and LBC) separately. Most data were not normally distributed, with a right skew attributable to natural heterogeneity (mottling of metals) in sediments. For nonparametric data, Kruskal-Wallis tests were used for multiple variable comparisons, and the median or sign test 
was used for paired analysis. Where distributions were found to be normal, the equivalent analyses of variance and paired $t$-tests were used. Pearson correlations between porewater metal content and chemical parameters were used when assumptions were met (normality, linearity, homoscedasticity). For nonparametric data, Spearman's rank test was used to determine correlations. All statistical tests were conducted in RStudio, ver 0.98.1102.

The Biotic Ligand Model (BLM) program (Ver 3.1.2.37; Windward Environmental) was used to calculate Zn-BLM chronic 5\% hazardous concentrations for Ceriodaphnia dubia. Assumptions included sulfide concentrations ranging from $0.001 \mathrm{mg} \mathrm{L}^{-1}$ on day 1 to $0.00599 \mathrm{mg} \mathrm{L}^{-1}$ on day 32 to reflect increases in measured AVS. Alkalinity was calculated using a $p \mathrm{CO}^{2}$ of 3.5 assuming an open system. Due to insufficient porewater samples sizes, unmeasured parameters $\left(\mathrm{Na}, \mathrm{K}, \mathrm{SO}_{4}\right.$, and $\mathrm{Cl}$ ) needed to be estimated and were done so per BLM recommendations with reference to Appendix $\mathrm{C}$ of the US Environmental Protection Agency's (USEPA's) aquatic life ambient freshwater quality criteria for $\mathrm{Cu}$ [19]. These parameters were a lower priority for analyzing from the limited sample volume because they are less influential in predicting $\mathrm{Zn}$ toxicity than other inputs, such as $\mathrm{pH}$ and $\mathrm{Ca}[20]$.

\section{RESULTS}

\section{Site comparison}

The most obvious and potentially important difference between sediments is the sediment texture, in addition to loss on ignition $(\% \mathrm{C})$, sediment $\mathrm{pH}$, and metal content. Important differences between sites are illustrated in Table 1. Particle size distribution indicates EB and QC are coarse sandy sediments, LBC is a sandy loam, and DRW is a sandy clay loam. Percent by weight of carbon (from loss on ignition) was statistically higher for DRW and LBC than for EB and QC $(p<0.01)$. Three statistical groupings for porewater DOC included high (LBC), moderate (QC), and low (EB and DRW; $p<0.01$ ). Sediment $\mathrm{pH}$ was statistically different on average between all sites, where LBC was most acidic, followed by DRW, QC, and EB ( $p=0.001)$.

Porewater concentrations of $\mathrm{Cu}, \mathrm{Fe}, \mathrm{Mn}$, and $\mathrm{Zn}$ were statistically highest in LBC $(p<0.004)$. For $\mathrm{Cu}$ and $\mathrm{Zn}$, there were 2 statistical groupings of high metal content (mean, $3.5 \pm 0.6 \mu \mathrm{g} \mathrm{L}^{-1} \mathrm{Cu}$ and $159.3 \pm 16.5 \mu \mathrm{g} \mathrm{L}^{-1} \mathrm{Zn}$ ) in LBC and low metal content (mean, $0.6 \pm 0.2 \mu \mathrm{g} \mathrm{L}^{-1} \mathrm{Cu}$ and $7.0 \pm 4.6$ $\mu \mathrm{gL}^{-1} \mathrm{Zn}$ ) in DRW, EB, and QC. For higher-concentration metals $\mathrm{Fe}$ and $\mathrm{Mn}, 3$ statistical groupings existed for LBC (mean, $14.8 \pm 1.8 \mathrm{mg} \mathrm{L}^{-1} \mathrm{Fe}$ and $2.2 \pm 0.2 \mathrm{mg} \mathrm{L}^{-1} \mathrm{Mn}$ ), DRW (mean, $6.8 \pm 0.7 \mathrm{mg} \mathrm{L}^{-1} \mathrm{Fe}$ and $0.9 \pm 0.1 \mathrm{mgL}^{-1}$ $\mathrm{Mn}$ ), and $\mathrm{EB}$ and QC (mean, $1.4 \pm 0.1 \mathrm{mgL}^{-1} \mathrm{Fe}$ and $0.4 \pm 0.03 \mathrm{mg} \mathrm{L}^{-1} \mathrm{Mn}$ ). Reduced Fe concentrations followed this trend as well. Porewater $\mathrm{Ca}, \mathrm{Mg}$, and $\mathrm{Ni}$ were similar between sites. Total metals analysis showed higher metal concentrations for LBC and DRW than for QC and EB, as shown in Table 1.

When comparing sulfide concentrations in sediments, EB had less AVS on average than the other sites (mean, $0.8 \pm 0.3 \mathrm{vs}$ $3.4 \pm 0.9 \mu \mathrm{mol} \mathrm{S}{ }^{2-} \mathrm{g}^{-1}$ dry $\left.\mathrm{wt} ; p=0.001\right)$. As normalized for organic carbon, SEM-AVS varied between most sites. From highest (theoretically most toxic) to lowest (theoretically nontoxic), the 3 groupings were LBC and DRW, EB (and DRW), and QC (and EB) (Table 1; $p<0.02$ ).

Higher concentrations of $\mathrm{Mn}$ and $\mathrm{Fe}$ in LBC and DRW sediments led to higher fractions of Fe oxides, Mn oxides, and $\mathrm{Zn}$ bound to $\mathrm{Fe} / \mathrm{Mn}$ oxides in these sediments than in QC and $\mathrm{EB}$ $(p<0.001)$. Average total oxidized concentration for high and low statistical groupings were $71.1 \pm 3.8$ and $8.6 \pm 1.4 \mu \mathrm{mol}$ Fe $\mathrm{g}^{-1}$ dry wt, $3.2 \pm 1.7$ and $0.9 \pm 0.7 \mu \mathrm{mol} \mathrm{Mn} \mathrm{g}{ }^{-1}$ dry wt, and $3.0 \pm 1.3$ and $0.6 \pm 0.2 \mu \mathrm{mol} \mathrm{Zng}^{-1}$ dry wt. Many of the differences between sites are likely related to site hydrology, as LBC and DRW are low-energy (depositional) riverine wetlands, whereas EB and QC are high-energy (less depositional) lacustrine, fringing wetlands.

\section{Seiche experiment}

After the 15-h drying period, surface sediments remained partially saturated and chemically reduced. After inundation, sediment moisture content increased by a range of $1 \%$ to $15 \%$ (average change, $10.0 \pm 2.4 \%$ ), from $39.1 \pm 7.5 \%$ to $49.0 \pm 9.2 \%$ on average. Sites with a sandy soil texture (EB and QC) had the highest change in moisture content, compared with sandy loam (LBC) and sandy clay loam (DRW) sediments. After inundation, $\mathrm{pH}$ decreased for $\mathrm{LBC}$ and $\mathrm{DRW}$ microcosms by $0.6 \pm 0.05(p \leq 0.035)$, from 6.8 to $6.3 \pm 0.03$, but there was no change for QC or EB. The $\mathrm{pH}$ remained neutral in all microcosms (range, 6.0-7.4; average, 6.7 \pm 0.3 ). A decrease in porewater $\mathrm{Fe}^{2+}$ concentration between saturated and inundated phases suggests sediment oxidation $(p<0.002)$. Although the $\mathrm{Fe}^{2+}$ decrease was observed for all microcosms, as individual sites, it was only significant for DRW $(p=0.04)$. We observed no change in porewater dissolved oxygen content $(0-1 \mathrm{~cm})$ after inundation.

All measured porewater metals-including $\mathrm{Ca}, \mathrm{Cu}, \mathrm{Fe}, \mathrm{Mg}$, $\mathrm{Mn}, \mathrm{Ni}$, and $\mathrm{Zn}$ - decreased in concentration after inundation of sediments (Figure 3). A significant decrease in $\mathrm{Zn}$ resulted from inundation ( $p=0.00006)$, largely because of decreases of $\mathrm{Zn}$ in sandy sediment microcosms (QC and EB). Likewise, a decrease in $\mathrm{Ca}$ and $\mathrm{Mg}(p \leq 0.02)$ occurred from $64.5 \pm 6.5$ to $47.0 \pm 4.7$ $\mathrm{mg} \mathrm{L}^{-1} \mathrm{Ca}$ and from $188.0 \pm 11.6$ to $157.1 \pm 9.4 \mathrm{mg} \mathrm{L}^{-1} \mathrm{Mg}$ for all sites on average. Decreases in $\mathrm{Ca}$ and $\mathrm{Mg}$ were only significant

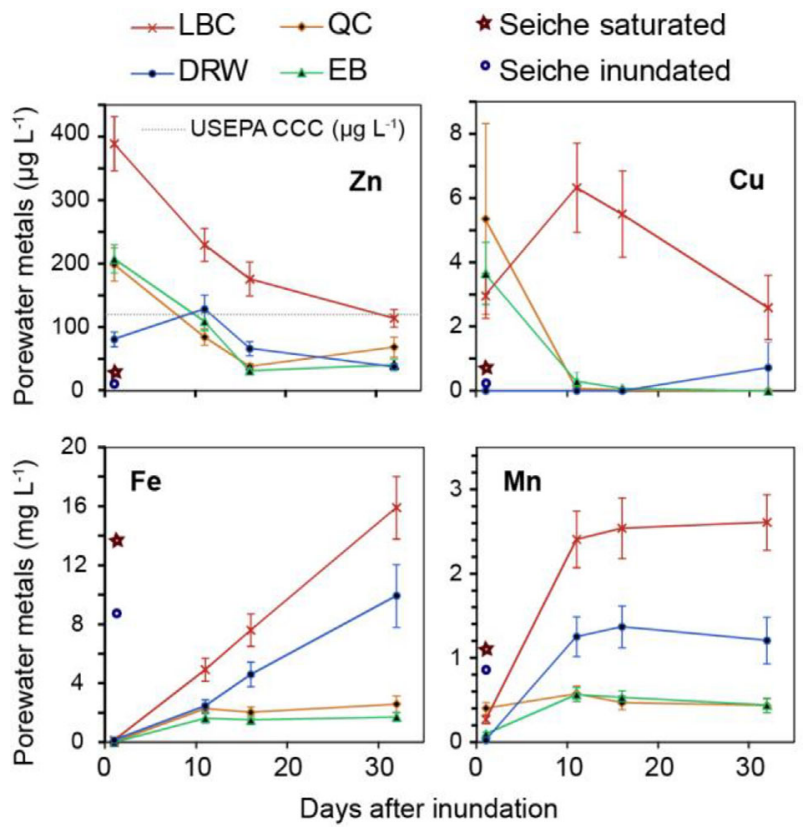

Figure 3. Average $\mathrm{Zn}, \mathrm{Cu}, \mathrm{Fe}$, and $\mathrm{Mn}$ in porewater for seiche (saturated and inundated) and drought experiments. Averages were calculated, including all depths \pm standard error $(n=3)$ for each sediment type (drought) or all depths and sediment types \pm standard error $(n=12)$ for seiche. Zinc exceeds the US Environmental Protection Agency recommended water quality criteria for aquatic life $\left(120 \mu \mathrm{gL}^{-1}\right)$ [21]. See Figure 1 for definition of site abbreviations. 
for LBC and EB on the single-site level $(p<0.05)$. Other decreases $(\mathrm{Cu}, \mathrm{Fe}, \mathrm{Mn}$, and $\mathrm{Ni})$ were not significant on the multisite level; however, Fe decreased in $\mathrm{LBC}$ from $39.5 \pm 4.6$ to $21.0 \pm 5.0 \mathrm{mg} \mathrm{L}^{-1}(p<0.04)$. Nevertheless, results for $\mathrm{Cu}$ and $\mathrm{Ni}$ may be misleading because concentrations were occasionally below detection.

All sediments from the seiche experiment had a negative average SEM-AVS when normalized to organic carbon (Figure 4), indicating theoretically non-toxic sediments as a result of sulfide binding. Increased variability for DRW and QC sediments was likely attributable to wide-ranging AVS values caused by strong vertical redox gradients. In other words, DRW and QC sediments had a strongly defined oxic $(\approx 0-1.5 \mathrm{~cm})$ and reduced layers $(\approx 1.5-3 \mathrm{~cm})$. On average, saturated and inundated sediments showed no differences in SEM-AVS on the single-site or multi-site level.

In addition, no differences in total, amorphous, or crystalline oxidized $\mathrm{Fe}$ content were observed between saturated and inundated sediments. Average total and amorphous oxidized Fe values between all sediments were $131.8 \pm 21.8$ and $43.9 \pm 7.6$ $\mu \mathrm{mol} \mathrm{Fe}{ }^{-1}$ dry wt, respectively. This suggests metal binding to Fe-oxyhydroxides is unchanged during seiche events. As shown in Figure 5, porewater hardness decreased between saturated and inundated phases for EB and LBC $(p<0.05)$, suggesting formation of metal bicarbonates.

\section{Drought experiment}

After $32 \mathrm{~d}$ of drying, sediment was oxic with no extractable porewater. Sediment moisture increased after inundation by a range of $8 \%$ to $32 \%$ (average, $24.8 \pm 4.5 \%$ ), from $17.7 \pm 2.5 \%$ to $45.3 \pm 7.5 \%$ on average. The sandy clay loam (DRW) sediments had a very small increase in water content $(8.5 \%)$ compared with the sandy and sandy loam sediments. Throughout the experiment, sediment $\mathrm{pH}$ either increased (for LBC and DRW, from 6.4 to $6.7 \pm 0.06$ ) or stayed the same (QC and $\mathrm{EB}$ ). This suggests that $\mathrm{QC}$ and $\mathrm{EB}$ have a greater apparent acid buffering capacity than LBC and DRW. The $\mathrm{pH}$ stability in QC/EB may also be attributable to lower concentrations of iron sulfides in these sediments. Dissolved oxygen in porewater

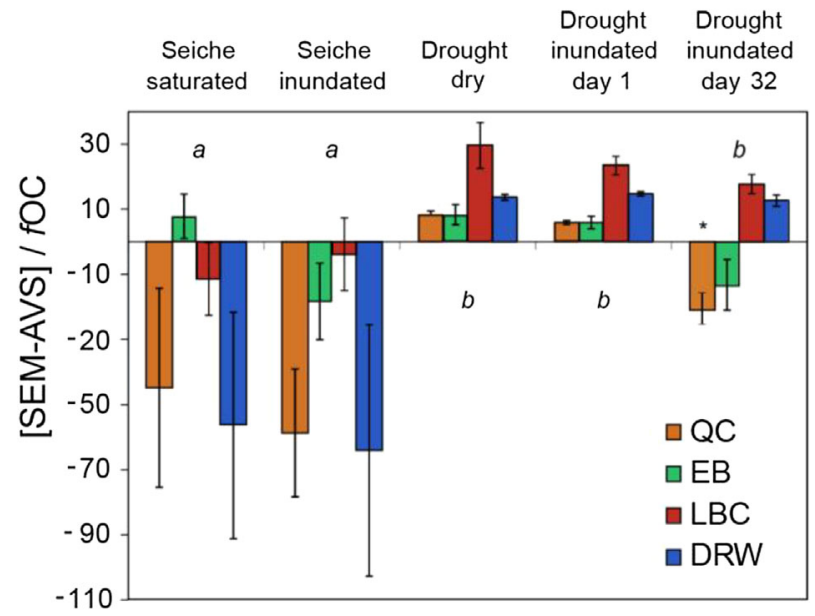

Figure 4. (SEM-AVS)/fOC ( \pm standard error) for seiche and drought experiments. Statistical differences between experiments $(a / b)$ and within experiments $(*)$ are shown $(p<0.05)$. Values are mostly negative during seiche experiment but become positive during drought, indicating higher potential toxicity. See Figure 1 for definition of site abbreviations. (SEMAVS) $/ f \mathrm{OC}=$ simultaneously extracted metals minus acid volatile sulfide over the fraction of organic carbon.

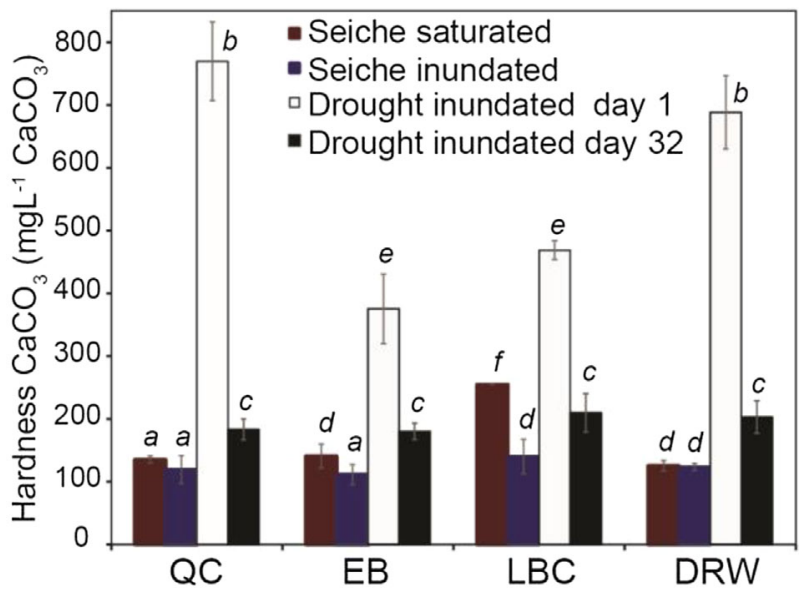

Figure 5. Porewater hardness ( \pm standard error) for seiche and drought experiments, with lettering for statistical significance $(p<0.05)$. Porewater hardness shows highest carbonate dissolution on day 1 inundation of the drought experiment and near return to seiche conditions after $32 \mathrm{~d}$. See Figure 1 for definition of site abbreviations.

(0-2 $\mathrm{cm}$ depth) decreased on average during the 32-d inundation, whereas $\mathrm{Fe}^{2+}$ concentration increased, indicating sediment reduction (Supplemental Data, Figure S1). When considering all sites, $\mathrm{Fe}^{2+}$ concentrations increased among days $1,3,9$, and $16(p<0.001)$.

As predicted, inundation of oxidized sediments led to increased porewater $\mathrm{Zn}$ and $\mathrm{Cu}$, which then decreased over $32 \mathrm{~d}$ (Figure 2). The observed increase in porewater $\mathrm{Zn}$ for LBC is especially notable, as it exceeded the USEPA threshold for chronic toxicity (CCC) to freshwater organisms $\left(120 \mu \mathrm{g} \mathrm{L}^{-1}\right)$ for approximately $30 \mathrm{~d}$ [21]. Both EB and QC exceeded the CCC, but only on day 1 after inundation, whereas DRW did not for either experiment (although it did in later trials with increased sediment drying). For $\mathrm{Cu}$, however, $\mathrm{LBC}$ and DRW microcosms did not show a significant day 1 increase. These sediments had the highest loss on ignition $(p<0.05)$, which suggests a greater role of organic carbon in controlling $\mathrm{Cu}$ partitioning.

We observed the opposite trend for Fe and Mn, where metals started in low concentrations and increased throughout the study (Figure 3). This effect is likely the result of reductive dissolution of $\mathrm{Fe} / \mathrm{Mn}$ in sediments, as reflected in the formation of reduced Fe. Iron and Mn sampling concentrations measured on day 1 after inundation were lower than on days 11, 16, and 32 $(p<0.00001)$. The only exception to this trend was for $\mathrm{Mn}$ concentrations in the $\mathrm{QC}$ microcosms, which were all similar.

Oxidized sediments pre-inundation and $24 \mathrm{~h}$ after inundation had a positive average SEM-AVS of $13.6 \pm 1.50$, as normalized to organic carbon, which suggests potential sediment toxicity to benthic macroinvertebrates (Figure 4). Because all microcosms had AVS concentrations of $0 \mu \mathrm{molg}^{-1}$ on day 1 after inundation, SEM-AVS became positive. After $32 \mathrm{~d}$ of inundation, SEM-AVS decreased for all sites except DRW. On the multi-site level, decreases in SEM-AVS were not significant (likely because of the small sample size); however, QC's decreases were significant $(p=0.001)$.

No difference in total, amorphous, or crystalline Fe/Mnoxyhydroxide content occurred between oxidized and inundated sediments at the experiment or site scale. Average total and amorphous oxidized $\mathrm{Fe}$ between all sediment types was $98.5 \pm 17.6$ and $33.2 \pm 5.8 \mu \mathrm{mol} \mathrm{Fe} \mathrm{g}^{-1}$ dry wt, respectively. In addition, a large fraction of total $\mathrm{Zn}(63.5 \pm 1.4 \%)$ was bound 
to Fe/Mn-oxyhydroxide minerals between all sites. The only phase that decreased after inundation was the amorphous Fe/Mn-oxyhydroxide-bound $\mathrm{Zn}(p=0.055)$. Carbonate in sediment and porewater may have also influenced metal flux, as porewater hardness decreased between day 1 and day 32 of inundation (from $477.8 \pm 46.3$ to $152.1 \pm 11.3 \mathrm{mg} \mathrm{L}^{-1}$ as $\left.\mathrm{CaCO}_{3} ; p<0.0000001\right)$, suggesting precipitation of metal bicarbonates (Figure 5).

\section{Comparison of seiche and drought}

Our prediction that metal flux would be greater in the drought experiment than the seiche was correct for several metals. Porewater concentrations of $\mathrm{Ca}, \mathrm{Cu}, \mathrm{Mg}$, and $\mathrm{Zn}$ were greater on average (all days) in the drought experiment than in the seiche experiment $(p<0.001)$. For porewater Fe (total and reduced fractions), conversely, seiche-induced sediments had higher concentrations than drought sediments $(p=0.008)$. Reduced Fe concentration was also greater in seiche sediment, with $4.0 \pm 0.4 \mathrm{mg} \mathrm{L}^{-1} \mathrm{Fe}^{2+}$ as compared with $2.3 \pm 0.2 \mathrm{mg} \mathrm{L}^{-1}$ $\mathrm{Fe}^{2+}$ in drought sediment. Porewater concentrations of $\mathrm{Ni}$ and Mn were similar between experiments.

The potential for sediment toxicity as SEM-AVS normalized to organic carbon was statistically different between the seiche and drought experiments $(p<0.0001)$. Whereas this value stayed mostly negative during the seiche event (mean, $-29.8 \pm 8.2$ ), it was mostly positive during the drought oxidation event (mean, 8.9 \pm 1.9 ), suggesting that droughtinducing conditions create higher theoretical risk of toxicity. All sediment sampled during both experiments had similar oxidized Fe content. Sediment $\mathrm{pH}$ was on average greater in the drought experiment than the seiche experiment (mean, $6.9 \pm 0.03$ vs $6.6 \pm 0.08 ; p<0.000001)$.

Some measured parameters, such as DOC in porewater and sediment loss on ignition, were not affected by hydrologic manipulations. Sediment organic matter was similar throughout the seiche and drought experiments (mean, $0.13 \pm 0.04 \% \mathrm{C}$ ). Porewater DOC was similar for all microcosms between all experiments; however, one exception was a statistical decrease in DOC for EB during the drought experiment (mean, $1.1 \pm 0.3$ to $\left.0.5 \pm 0.2 \mathrm{mg} \mathrm{L}^{-1} \mathrm{C} ; p<0.02\right)$.

\section{DISCUSSION}

\section{Assessing ecological risk of seiche and drought}

The magnitude of chemical change observed during the simulated seiche is relatively unconcerning from a biological perspective. Metals concentrations did not exceed CCC, with SEM-AVS as normalized for organic carbon remaining negative. The $\mathrm{pH}$ decrease observed for LBC and DRW may indicate oxidation or increased microbial production after inundation of sediments. Several species of amphipods can be sensitive to acidification with changes to $\mathrm{pH}$ of $>0.7$ units, although this is mostly an issue in warmer-temperature water with low $\mathrm{pH}(<6)[22,23]$. Although the magnitude of sediment acidification in LBC and DRW during the seiche was less than 0.7, field-monitoring efforts should consider large-scale changes in sediment $\mathrm{pH}$ with water fluctuation events, as the magnitude may vary. Porewater metal concentrations typically increase with acidification, but the opposite was observed in the present study. It is possible that metals leached from the microcosm chambers, as some drainage occurred in attempt to emulate groundwater dynamics. Seiche, tides, and other shortterm water level fluctuations raise and lower the water table in accordance with water level. As the water table lowers, porewater leaches from wetland sediment; however, re-inundation would include metal-rich groundwater inputs (which our experimental design did not include) [24]. In field settings, we would still expect porewater metals to increase with a $\mathrm{pH}$ decrease, despite these findings.

The increase in porewater $\mathrm{Zn}$ after inundation of drought/ oxidized sediments is an ecological concern, because it may adversely affect benthic macroinvertebrates inhabiting metalcontaminated sediment. Although QC, EB, and LBC all exceeded the USEPA threshold for chronic toxicity, LBC was the only site in exceedance when compared with the hardness corrected criteria (Figure 6). However, recent studies using a BLM for $\mathrm{Zn}$ show that chronic toxicity to organisms is often underestimated using the hardness corrected criteria [20], particularly for $C$. dubia. In the present study, we found the hardness corrected criteria to be somewhat underprotective as compared with the Zn-BLM for 2 of our sites (EB on day 1 and LBC on days 1-16). The BLM is designed to address environmental risk to surface water organisms and not benthic organisms exposed to porewater; however, it is more mechanistic and chemically descriptive than current theoretical models or screening methods for sediments such as SEM-AVS or probable-effects concentrations. A sediment BLM that can accurately predict metal bioavailability where organic carbon is the primary binding ligand has been produced; however, it is not yet fully applicable to field settings or designed to account for changing redox conditions [25]. Future model development is needed to accurately incorporate benthic species into the BLM or similar user-friendly and mechanistically driven model.

Although the probability of toxic effects to organisms associated with $\mathrm{Zn}$ pulsing is debatable, one study confirmed its occurrence during field sampling in a similar watershed [14]. In Krieling et al. [14], porewater ion content measured by a plant root simulator (PRS) showed increasing Zn concentrations with sediment oxidation in a floodplain of the upper Mississippi River (WI, USA). Further, in White et al. [26], species richness in high-carbonate lakes (in Great Lakes region) was found to be

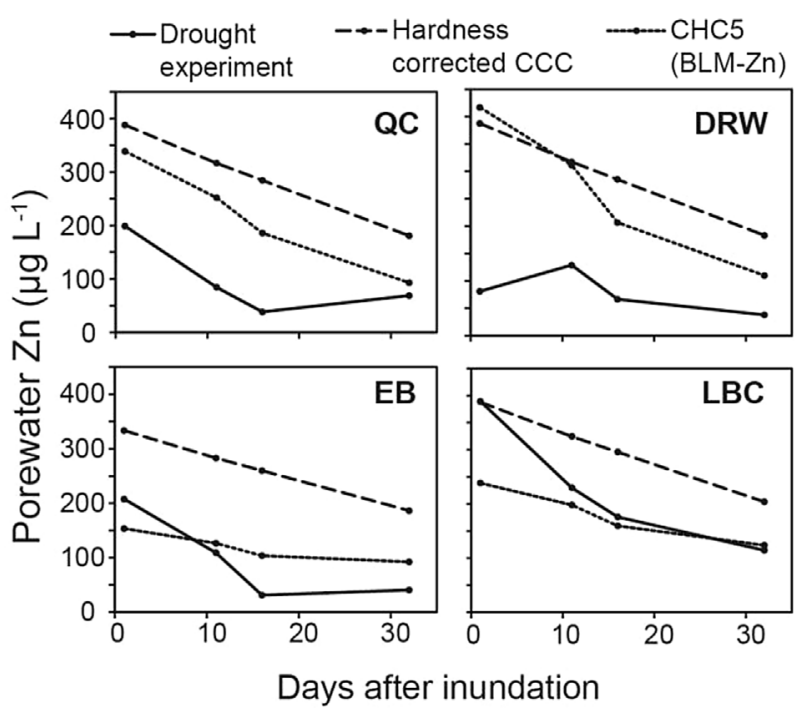

Figure 6. Porewater Zn concentrations compared to hardness-corrected US Environmental Protection Agency threshold for chronic toxicity (CCC) [21] and Biotic Ligand Model (BLM)-derived chronic 5\% hazardous concentration (HC5) values for drought experiment. Exceedance of the CCC was observed in LBC only at the start of the experiment. The chronic HC5 suggests hardness-corrected criteria may occasionally be underprotective for $\mathrm{EB}$ and $\mathrm{LBC}$ sites. See Figure 1 for definition of site abbreviations. 
highest when the magnitude of water fluctuation remained unchanged from year to year. The loss of species richness was weakly correlated to water quality (DOC, $\mathrm{Ca}^{2+}$, Conductivity, $\mathrm{pH}, \mathrm{SO}_{4}{ }^{2-}$ ), although metal analyses were not included in the study. These 2 lines of evidence, in conjunction with findings from the present study, suggest that field studies should be conducted to precisely assess impacts of $\mathrm{Zn}$ oxidative release.

In addition to the dissolved $\mathrm{Zn}$ porewater concentrations, SEM-AVS values are another line of evidence indicating sediments oxidized during drought may have increased theoretical toxicity to organisms. Several studies using Znspiked sediments have clearly shown that SEM-AVS values $>0$ are strongly correlated with metal toxicity to several macroinvertebrate species [27,28]. Despite these findings, others suggest it may not be appropriate in nonequilibrium systems because of differences in reaction kinetics of sulfide reduction between sediment types and the preference for less toxic microsites by organisms [29,30]. Regardless, it is still a useful tool to help predict metal binding to sulfide and organic matter in sediments, as well as metal bioavailability.

\section{Effects of sediment chemistry on redox-induced $\mathrm{Zn}$ pulse}

During the present experiments, several important metal binding phases were affected during drought conditions, including carbonates and sulfides. Sulfide (as AVS) and carbonate (in porewater) were moderately correlated with $\mathrm{Zn}$ in LBC porewater (correlation coefficient [cc] $=-0.64$, $p<0.01 ; \mathrm{cc}=0.59, p<0.001)$. This is strong evidence that porewater $\mathrm{Zn}$ increased after inundation due to oxidation of $\mathrm{Zn}$ sulfides and dissolution of $\mathrm{Zn}$ carbonates. A theoretical schematic of these reactions is provided as Figure 7. Zinc sulfides have been well studied and are known to be an important ligand for $\mathrm{Zn}$ bioavailability [31,32]. The mechanics of $\mathrm{Zn}$ carbonate formation and dissolution are less studied but are of considerable importance in high-carbonate systems [33]. Zinc carbonate precipitation may have increased during sediment drying, leading to increased dissolution after sediment inundation. This effect would be enhanced by the observed increase in sediment acidity on day 1.

It is somewhat surprising that there was not a clear change in sediment Fe/Mn-oxyhydroxide content (crystalline, amorphous, or total), especially in sediments with high Fe (DRW and LBC). Most studies show an overall decrease in sediment Fe/Mn-oxyhydroxide content with reduction, although these studies use homogenized (not heterogeneous) sediment. In more controlled studies, reductive dissolution of Fe/Mn-oxyhydroxides has been found to be important for porewater metal

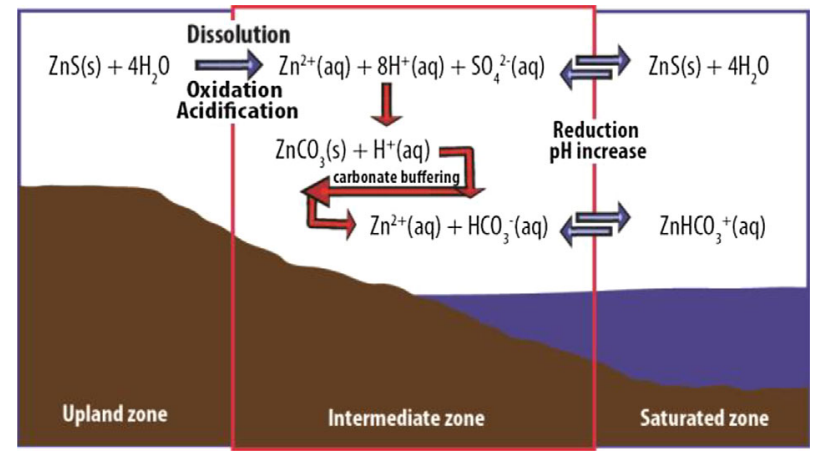

Figure 7. A schematic of the chemical equations associated with $\mathrm{Zn}$ oxidative release and subsequent reduction in high alkalinity sediments. equilibrium [34]. Further evidence using electron microscopy techniques shows the formation of $\mathrm{Zn}$ on and in amorphous ferrihydrite and vernadite-like minerals in oxidized sediments [35]. For other metals $(\mathrm{Cu}$ and $\mathrm{Ni})$, crystalline $\mathrm{Fe} / \mathrm{Mn}$ oxide content increases and amorphous $\mathrm{Fe} / \mathrm{Mn}$ oxide content decreases as oxic and anoxic sediment layers form with aging [36]. Sediment heterogeneity and mottling added to the complexity of this system such that more intensive sampling was likely needed to see effects to $\mathrm{Fe} / \mathrm{Mn}$-oxyhydroxide content. Further, sediment desiccation likely decreased microbial productivity, which would also decrease kinetic rates of $\mathrm{Fe} / \mathrm{Mn}$-oxyhydroxide transformation.

Although an overall decrease in $\mathrm{Zn}$ bound (through complexation or adsorption) to amorphous Fe/Mn-oxyhydroxides (ferrihydrite, lepidocrocite) was observed during the inundation, it was not correlated with porewater $\mathrm{Zn}$ concentrations $(p>0.25)$. This may indicate the amorphous Fe/Mn-oxyhydroxide- $\mathrm{Zn}$ is being reduced to a non-labile form, or the relationship is confounded by other ligands such as sulfide, carbonates, or particulate organic matter. Our findings agree in that the amorphous Fe/Mn-oxyhydroxides seem more important to $\mathrm{Zn}$ bioavailability than the crystalline phases, since we observed a change in $\mathrm{Zn}$ binding to amorphous but not crystalline Fe/Mnoxyhydroxides. This is likely attributable to the large surface area of amorphous compounds, which increases available binding sites [37].

Because porewater DOC did not change during the experiment, it is unlikely it influenced $\mathrm{Zn}$ bioavailability. Our sampling design; however, did not allow sampling of porewater particulate organic matter, which we would expect to become more sorptive to metals as $\mathrm{pH}$ increases. In future studies, we hope to measure the changes in metal binding to particulate organic matter with water level fluctuation.

Previous studies have shown inundation of oxidized sediment to cause toxicity in low acid-neutralizing capacity systems. Carvalho et al. [38] assessed impacts of resuspension on macroinvertebrate populations in the acid-sulfate sediments of Billings Reservoir, Brazil, in which sediment oxidation caused acute toxicity to Daphnia similis. Their findings, however, are only tangentially applicable to high-acid neutralizing capacity systems during water level fluctuations.

The present study shows that systems with relatively high $\mathrm{pH}$ and high buffer capacity can also release bioavailable metals into aquatic systems. Sediment $\mathrm{pH}$ was strongly correlated to porewater $\mathrm{Zn}$ for DRW and LBC sediments only, during the drought experiment $(\mathrm{cc}=-0.5, p<0.0001)$. Well-buffered QC and $\mathrm{EB}$ sediments did not experience a $\mathrm{pH}$ change, allowing $\mathrm{Zn}$ to be rapidly re-adsorbed to sediments after the initial inundation. In these experiments, hydrology has proved important in (at least) 2 aspects. First, it shapes sediment characteristics from allotchtonous inputs, which alters grain size, nutrient inputs, and general chemical composition. Second, it directs the chemical equilibrium of sediments and thus the bioavailability of metal contaminants.

\section{Implications for climate research}

Our findings suggest additional focus is needed to predict biogeochemical effects of climate variability on affected aquatic systems. Our regional focus was the lower Great Lakes, where increased variability in water levels has occurred in recent years, ranging from record lows (2013) to surges of 0.6 to $1 \mathrm{~m}$ in lake water levels (2014) [39]. This hydrologic variability is correlated with surface water temperatures, the duration and coverage of winter lake ice, evaporation, and precipitation, all 
factors influenced on a regional scale by El Niño climatic events and weakening of the circumpolar vortex [40]. Both of these climatic phenomena are expected to strengthen with continued climatic warming, further increasing variability in Great Lakes water levels [41]. Strong evidence suggests the metal pulse we observed in our experimental microcosms is occurring in coastal sediments of the Great Lakes. If so, this could have important biogeochemical ramifications for these aquatic systems.

As a lab microcosm study, the present research has a few limitations to its field applicability, including the absence of plants and autochthonous inputs. The presence of plants can add new organic carbon to sediments, and plant rhizospheres can alter the oxidation of sediments, which influences metal binding [42]. With these important distinctions in mind, the data and results of the present research can be broadly applied to freshwater aquatic systems.

Although the present study shows increased bioavailability of metals in just one aquatic system (high-carbonate coastal freshwater wetlands), similar biogeochemical effects are predicted for riparian and inland freshwater aquatic systems. Our stated predictions were partially correct, in that sediment oxidation led to $\mathrm{Zn}$ release; long-term drying (drought) had a larger effect on theoretical toxicity than short-term drying (seiche); and dominant binding ligands associated with Zn-oxidative release were sulfide, carbonate, and amorphous Fe/Mn-oxyhydroxides. The redox-induced pulse of metals into sediment porewaters can lead to changes in nutrient availability, sediment chemistry, and environmental risk; therefore, sitespecific hydrochemical parameters should be considered when assessing sediment quality.

Supplemental Data-The Supplemental Data are available on the Wiley Online Library at DOI: 10.1002/etc.3783.

Acknowledgment-We thank the following lab staff for their support: J. Daley, S. Hudson, A. Harrison, G. Steigmeyer, M. Grundler, O. Rath, and M. Xiao. Special thanks to K. Farley for his careful review and insight. This research was supported in part by the Society of Wetland Scientists.

Data Availability-Data, associated metadata, and calculation tools are available from the corresponding author (snedrich@umich.edu).

\section{REFERENCES}

1. Firth P, Fisher SG. 1992. Global Climate Change and Freshwater Ecosystems. Springer-Verlag, New York.

2. Milly PCD, Dunne KA, Vecchia AV. 2005. Global pattern of trends in streamflow and water availability in a changing climate. Nature 438:347-350.

3. De Jonge M, Teuchies J, Meire P, Blust R, Bervoets L. 2012. The impact of increased oxygen conditions on metal-contaminated sediments part I: Effects on redox status, sediment geochemistry and metal bioavailability. Water Res 46:2205-2214.

4. Davranche M, Bollinger JC. 2000. Release of metals from iron oxyhydroxides under reductive conditions: Effect of metal/solid interactions. J Colloid Interface Sci 232:165-173.

5. Simpson SL, Apte SC, Batley GE. 1998. Effect of short-term resuspension events on trace metal speciation in polluted anoxic sediments. Environ Sci Technol 32:620-625.

6. Patterson JW, Allen HE, Scala JJ. 1977. Carbonate precipitation for heavy metals pollutants. J Water Pollut Control Fed 49:2397-2410.

7. Mahony JD, Di Toro DM, Gonzalez AM, Curto M, Dilg M, Derosa LD, Sparrow LA. 1996. Partitioning of metals to sediment organic carbon. Environ Toxicol Chem 15:2187-2197.

8. Calmano W, Hong J, Forstner U. 1993. Binding and mobilization of heavy metals in contaminated sediments affected by $\mathrm{pH}$ and redox potential. Water Sci Technol 28:223-235.

9. Creeper NL, Shand P, Hicks W, Fitzpatrick RW. 2015. Porewater geochemistry of inland acid sulfate soils with sulfuric horizons following postdrought reflooding with freshwater. J Environ Qual 44:989-1000
10. Mosley LM, Fitzpatrick RW, Palmer D, Leyden E, Shand P. 2014 Changes in acidity and metal geochemistry in soils, groundwater, drain and river water in the Lower Murray River after a severe drought. Sci Total Environ 485-486:281-291.

11. Sapsford DJ, Bowell RJ, Dey M, Williams KP. 2009. Humidity cell tests for the prediction of acid rock drainage. Miner Eng 22:25-36.

12. Kinsman-Costello LE, O'Brien J, Hamilton SK. 2014. Re-flooding a historically drained wetland leads to rapid sediment phosphorus release. Ecosystems 17:641-656.

13. Simpson SL, Ward D, Strom D, Jolley DF. 2012. Oxidation of acidvolatile sulfide in surface sediments increases the release and toxicity of copper to the benthic amphipod Melita plumulosa. Chemosphere 88:953-961.

14. Kreiling RM, De Jager NR, Swanson W, Strauss Ea, Thomsen M. 2015. Effects of flooding on ion exchange rates in anual upper Mississippi River floodplain forest impacted by herbivory, invasion, and restoration. Wetlands 35:1005-1012.

15. Seybold CA, Mersie W, Huang J, Mcnamee C. 2002. Soil redox, pH, temperature, and water-table patterns of a freshwater tidal wetland. Wetlands 22:149-158.

16. Viollier E, Inglett PW, Hunter K, Roychoudhury AN, Van Cappellen P. 2000. The ferrozine method revisited: $\mathrm{Fe}$ (II)/Fe (III) determination in natural waters. Appl Geochem 15:785-790.

17. Allen HE, Fu G, Boothman W, Di Toro DM, Mahoney JD. 1991. Determination of acid volatile sulfide and selected simultaneously extractable metals in sediment. EPA 821/R-91/100. US Environmental Protection Agency, Washington, DC.

18. Kostka JE, Luther GW. 1994. Partitioning and speciation of solid phase iron in saltmarsh sediments. Geochim Cosmochim Acta 58:1701-1710.

19. US Environmental Protection Agency. 2007. Aquatic Life Ambient Freshwater Quality Criteria-Copper, 2007 Revision. EPA 822/R-07/ 001. Washington, DC.

20. Deforest DK, Van Genderen EJ. 2012. Application of U.S. EPA guidelines in a bioavailability-based assessment of ambient water quality criteria for zinc in freshwater. Environ Toxicol Chem 31:1264-1272.

21. US Environmental Protection Agency. 2016. National Recommended Water Quality Criteria-Aquatic Life Criteria table. [cited 2016 February 7]. Available from: http://www.epa.gov/wqc/nationalrecommended-water-quality-criteria-aquatic-life-criteria-table

22. France RL, Stokes PM. 1987. Life stage and population variation in resistance and tolerance of Hyalla azteca (amphipoda) to low $\mathrm{pH}$ Canada J Fish Aquat Sci 44:1102-1111.

23. Pilgrim W, Burt MDB. 1993. Effect of acute $\mathrm{pH}$ depression on the survival of the freshwater amphipod Hyalella azteca at variable temperatures: Field and laboratory studies. Hydrobiologia 254:91-98.

24. Taniguchi M, Fukuo Y. 1996. An effect of seiche on groundwater seepage rate into Lake Biwa, Japan. Water Resour Res 32:333-338.

25. Shi Z, Di Toro DM, Allen HE, Sparks DL. 2013. A general model for kinetics of heavy metal adsorption and desorption on soils. Environ Sci Technol 47:3761-3767.

26. White MS, Xenopoulos MA, Hogsden K, Metcalfe RA, Dillon PJ 2008. Natural lake level fluctuation and associated concordance with water quality and aquatic communities within small lakes of the Laurentian Great Lakes region. Hydrobiologia 613:21-31.

27. Han J, Ma D, Quan X, Wang J, Yan Q. 2005. Bioavailability of zinc in the sediment to the estuarine amphipod Grandidierella japonica. Hydrobiologia 541:149-154.

28. Lee J-S., Lee J-H. 2005. Influence of acid volatile sulfides and simultaneously extracted metals on the bioavailability and toxicity of a mixture of sediment-associated $\mathrm{Cd}, \mathrm{Ni}$, and $\mathrm{Zn}$ to polychaetes Neanthes arenaceodentata. Sci Total Environ 338:229-241.

29. Brown CL. 2000. Influence of acid volatile sulfides and metal concentrations on metal partitioning in contaminated sediments. Environ Sci Technol 34:4511-4516.

30. Simpson SL, Ward D, Strom D, Jolley DF. 2012. Oxidation of acid-volatile sulfide in surface sediments increases the release and toxicity of copper to the benthic amphipod Melita plumulosa. Chemosphere 88:953-961.

31. Simpson SL, Apte SG, Batley GE. 2000. Effect of short-term resuspension events on the oxidation of cadmium, lead, and zinc sulfide phases in anoxic estuarine sediments. Environ Sci Technol 34:4533-4537.

32. de Livera J, McLaughlin MJ, Hettiarachchi GM, Kirby JK, Beak DG 2011. Cadmium solubility in paddy soils: Effects of soil oxidation, metal sulfides and competitive ions. Sci Total Environ 409:1489-1497.

33. Korfali SI, Davies BE. 2004. Speciation of metals in sediment and water in a river underlain by limestone: Role of carbonate species for purification capacity of rivers. Adv Environ Res 8:599-612. 
34. Grybos M, Davranche M, Gruau G, Petitjean P. 2007. Is trace metal release in wetland soils controlled by organic matter mobility or Fe-oxyhydroxides reduction? J Colloid Interface Sci 314:490-501.

35. Hochella MF, Moore JN, Putnis CV, Putnis A, Kasama T, Eberl DD. 2005. Direct observation of heavy metal-mineral association from the Clark Fork River Superfund Complex: Implications for metal transport and bioavailability. Geochim Cosmochim Acta 69:1651-1663.

36. Costello DM, Hammerschmidt CR, Burton GA. 2015. Copper sediment toxicity and partitioning during oxidation in a flow-through flume. Environ Sci Technol 49:6926-6933.

37. Guo S, Liu Z, Li Q, Yang P, Wang L, He B-Y., Xu Z-M., Ye J-S., Yeng EY. 2016. Leaching heavy metals from the surface soil of reclaimed tidal flat by alternating seawater inundation and air drying. Chemosphere 157:262-270.
38. Carvalho PSM, Zanardi E, Buratini SV, Lamparelli MC, Martins, Magali C. 1998. Oxidizing effect on metal remobilization and Daphnia similis toxicity from a Brazilian reservoir sediment suspension. Water Res 32:193-199.

39. Gronewold AD, Stow CA. 2014. Unprecedented seasonal water level dynamics on one of the earth's largest lakes. Bull Am Meteorol Soc 95:15-17.

40. Gronewold AD, Stow CA. 2014. Water loss from the Great Lakes. Science 343:1084-1085.

41. Cai W, Borlace S, Lengaigne M, van Rensch P, Collins M, Vecchi G, Timmermann A, Santoso A, McPhaden MJ, Wu L, England MH, Wang G, Guilyardi E, Jin F-F. 2014. Increasing frequency of extreme El Niño events due to greenhouse warming. Nat Clim Chang 5:1-6.

42. Jacob DL, Otte ML. 2003. Conflicting processes in the wetland plant rhizosphere: Metal retention or mobilization? Water Air Soil Pollut 3:91-104. 